\title{
AMAR MA'RUF DAN NAHI MUNKAR (Suatu Pendekatan Hadis Dakwah dalam Perubahan Sosial)
}

\author{
Dr. Muhammad Sabir, M.Ag ${ }^{1}$ \\ Universitas Islam Negeri Makassar (UINAM) \\ muhammad.sabir@yahoo.com
}

\begin{abstract}
Prophet of Muhammad saw was commanded to missionize in Mekkah to the Arab community. This mission movement brought social change that happened in the field of religion, moral, and law. Prophet of Muhammad saw was delegated to perform amarma'ruf (goodness command) and Nahi Munkar (forbidden goodlessness), fought to against injustice and arbitrary was done by Arab community of Jahiliyah in Makkah. Prophet of Muhammad saw came free human being of behavior, moral, errant, grind, slavery, social difference, and build society pursuant to belief in Allah swt.

Prophet of Muhammad saw performed mission confronted to condition of society which obeyed to tradition. Powers and conglomerate pout, affronting that Muhammad came from impecunious family, illiteracy and orphan. Nevertheless, Prophet of Muhammad saw was always determined, and patient perform mission even though was affronted and reputed crazy.Performed by revolution Prophet of Muhammad saw was revolution totally touching all human life aspect, touching behavior of jahiliyah intent on civilization, virulent intent on good behavior, slavery go to brotherhood, insincerity go to trust, grind of woman clan go to clarification and order free life human being in compliance to Allah. Attendance of Prophet of Muhammad gave bliss and expectation for all human being, even all creatures exists in this earth.
\end{abstract}

Keywords: Mission, goodness command, forbiddengodlessness, the Arab community.

Abstrak. Nabi Muhammad saw, diperintahkan berdakwah kepada kaum Arab di Makkah. Gerakan dakwah ini membawa perubahan sosial yang terjadi dalam bidang agama, moral, dan hukum.Nabi Muhammad saw, di utus untuk menjalankan amar ma'ruf dan Nahi Munkar melawan ketidakadilan, dan kesewenang-wenangan yang dilakukan oleh komunitas Arab Jahiliyah di Makkah. Nabi Muhammad saw, datang untuk membebaskan manusia dari akhlak, moral, kesesatan, penindasan, perbudakan, kesenjangan sosial, dan membangun masyarakat berdasarkan keimanan kepada Allah.

Nabi Muhammad saw dalam menjalankan dakwah dalam kondisi masyarakat yang taat kepada tradisi jahiliyyah. Penguasa, dan konglomerat mencibirkan, menghina bahwa Muhammad berasal dari keluarga miskin, yatim dan buta huruf. Meskipun demikian, Nabi Muhammad saw selalu tabah, dan sabar menjalankan dakwahnya meski harus dihina dan dianggap gila. Revolusi yang dilakukan Nabi Muhammad saw adalah revolusi menyeluruh yang menyentuh segala aspek kehidupan manusia, menyentuh perilaku jahiliyah menuju peradaban, jahat menuju perilaku baik, perbudakan menuju persaudaraan, kecurangan menuju kepercayaan, penindasan kaum perempuan menuju pencerahan dan menyuruh manusia hidup bebas dalam kepatuhan kepada Allah. Kehadiran Nabi Muhammad

\footnotetext{
1 Penulis adalah dosen Universitas Islam Negeri Makassar (UINAM), mengampu mata kuliah Ilmu Hadis pada Fakultas Syari'ah dan Hukum, Jurusan Ilmu Hukum.
} 
memberi harapan dan kebahagiaan bagi seluruh manusia, bahkan seluruh makhluk yang ada di bumi ini.

Kata Kunci: Dakwah, Amr Ma'ruf dan Nahi Munkar, Masyarakat Arab

\section{Pendahuluan}

Nabi Muhammad seorang revolusioner mempunyai tugas menegakkan supremasi hukum, pembebasan kaum lemah dan tertindas, membangun komunitas atas dasar egalitas sosial, cinta kasih (rahmah), keadilan ('adal) dan persaudaraan (ukhuwah). Pribadi Nabi Muhammad adalah seorang manusia biasa yang sama dengan manusia lainnya, hanya saja NabiMuhammad mendapatkan keistimewaan berupa wahyu oleh Allah swt untuk menjadi seorang Nabi dan Rasul.

Nabi Muhammad diberikan amanah untuk menjalankan amar ma'ruf dan nahi munkardan menyampaikannya dengan nilai-nilai agama secara harmonis, mengajak masyarakat dengan cara yang lembut, sopan, bijaksana, penuh kasih sayang, keteladan, beradab, dan damai. Bahkan Nabi Muhammad mampu menselaraskan antara das sollen dan das sein, dalam pengertian bahwa Nabi Muhammad memiliki hati langit tapi kaki tetap menjejak bumi (down to earth), sehingga menjadikan dirinya dipercaya oleh pengikutnya, konsisten dalam perjuangan dan ajaranya sesuai dengan hati manusia. Nabi Muhammad mengajaran vertikal kepada Allah dan horizontal sesama manusia dengan tidak hanya mengajarkan rukun Islam berupan salat, haji, zakat atau puasa yang baik, tetapi juga mengajari umat Islam melaksanakan fungsisosialnya untuk kepentingan umat manusia di muka bumi ini.

Ajaran Islam mengembangkan ajaran missi yang mewajibkan dakwah kepada umatnya untuk menyebarkan syiar agama, baik secara individu maupun kelompok. Sebagaimana tercantum dalam Q.S. Ali Imran [3]:104 Dan hendaklah ada di antara kamu segolongan umat yang mengajak kepada kebaikan, mengajak kepada yang ma'ruf dan mencegah dari yang munkar, mereka itulah orang-orang yang beruntung" Ayat ini secara tegas menunjukkan adanya suatu kewajiban berdakwah karena ada lam amar di dalam kalimat wal takun. Sedangkan kalimat minkum menunjukkan fardu kifayah, maka seluruh umat Islam 
diperintahkan agar sebagian mereka melaksanakan kewajiban ini. ${ }^{2}$

Al-Jashash menyatakan bahwa kata مِ dolam ayat ontuk menunjukkan sebagian."karena mengandung dua makna. Pertama, kewajiban amar ma'rufdan nahi munkar. Kedua, yaitu fardu kifayah. Jika telah dilaksanakan oleh sebagian, maka yang lain tidak terkena kewajiban".3 Ismail ibn Kasir menjelaskan bahwa setiap pribadi Muslim wajib berdakwah, namun secara khusus tugas itu diurus oleh kelompok umat Islam. ${ }^{4}$ Kewajiban menegakkan amar ma'ruf dan nahi munkar, merupakan hal yang sangat esensi dalam Islam, kehadirannya untuk membebaskan manusia dari keterbelakangan, ketertindasan, perbudakan, kebodohan, kemusyrikan, karena dakwah amar ma'ruf dan nahi munkarmerupakan perpanjangan tangan dari nabi/rasul kepada umatnya.Al-Qurtubi dalam Tafsirnya alJami'li Ahkam al Quran, menjelaskan lafaz مِنْكُمْنdalam ayat ini adalah untuk menunjukkan sebahagian (li al-tab'idh). Artinya juru dakwah itu mestilah dari

2 Abdul Karim Zaidan, Dasar-Dasar Dakwah, (Jakarta: Pustaka Firdaus, 1980), h. 9

${ }^{3}$ Al Jashash, Ahkamul Qur'an, Juz 2/29

4 Ismail Ibn Kasir, Tafsir al-Quran al'Azim, Juz 1, (Bairut: Dar al Ihya al-Turas al'Arabi,1069), h.390 kalangan ulama, sedangkan masyarakat itu tidak semuanya ulama. Dengan demikian mufassir ini menarik kesimpulan hukum bahwa tugas amar makruf dan nahi munkar itu adalah fardhu kifayah. ${ }^{5}$

Demikian besar keutamaan beramarma'rufkepada manusia, maka Nabi Muhammad menyatakan bahwa pahala menyuruh kepada kebaikan itu sepadan dengan pahala orang yang melakukannya dan pahala orang yang memerintahkan kepada kejahatan juga sepadan dengan orang yang melakukannya. ${ }^{6} \quad$ Orang-orang yang menyaksikan perbuatan aniaya yang dilakukan orang lain sedang seseorang tidak ada usaha mencegahnya, maka Allah swt akan memberikan siksaan yang sama dengan orang yang melalukan penganiayaan tersebut. Sebab seseorang yang menyaksikan berbuat maksiat seperti berzina tanpa pencegahan, maka dihitung seperti orang yang melakukan perbuatan tersebut.

Al-Ghazali, dalam kitabnya Ihya' Ulumuddin, seperti yang ditulis oleh Ahmad menegaskan bahwa aktivitas

5 Muhammad al-Qurtubi, al-Jami' li Ahkam al-Quran, Juz IV, (Bairut: Dar al-Kutub alArabiyyah, 1993), h.106

${ }^{6}$ Abu Daud, Juz IV: 201 dan Muslim, Juz IV: 2060 
amar ma'ruf dan nahi munkar adalah kutub terbesar dalam urusan agama. amar ma'ruf dan nahi munkaradalah sesuatu yang penting, dan karena misi itulah, maka Allah mengutus para nabi. Jika aktivitas amar ma'ruf dan nahi munkar hilang, maka syiar kenabian hilang, agama menjadi rusak, kesesatan tersebar, kebodohan akan merajalela, satu negeri akan binasa. Begitu juga umat secara keseluruhan. ${ }^{7}$

Keberhasilan dakwah Nabi dalam merubah masyarakat jahiliyah menuju peradaban tidak lepas dari tiga aspek yaitu: a) aspek intelektual,b) aspek psikologi, dan c) aspek perilaku. Yang disebut pertama adalah mengajak masyarakat jahiliyah untukberdialogdan musyawarah dalam berbagai hal khususnya pada kehidupan dunia dan kehidupan akhirat. Sedangkan disebut kedua adalah mempergunakan metode yang tepat tanpa paksaan,pendekatan personal, sehingga seseorang meresponnya tidak dalam keadaan tertekan, Nabiberbuat tanpa mengharapkan balasan, melakukannya dengan niat hati yang paling dalam, bertujuan menyelamatkan umat manusia dari kebodohan, kemusyrikan. Sedangkan yang disebut

${ }^{7}$ Ahmad Abdurraziq al-Bakri, Ringkasan Ihya 'ulumuddin Imam Ghazali cetakan ke VI. (Jakarta: Sahara Publishers, 2010), h.246 terakhir adalah bil uswatun hasanah, yaitu dengan memberi contoh akhlaqul karimahyang sangat mulia, yang baik dan cara penyampaian terpuji, sesuai dengan perbuatan dan perkataan,yang menyebabkan masyarakat jahiliyah banyak tertarik masuk Islam dengan kesadaran sendiri.Keberhasilan dakwah Nabi Muhammad saw banyak dibuktikan dalam realitas kehidupan sehari-hari dalam pergaulan.

Pada masa hidup Rasulullah, dengan kekuatan akhlaqul karimahyang ditransformasikan kepada kelompok masyarakat Arab jahiliyah menjadikan perubahan dari biadab menjadi beradab, dari jahiliyah menjadi ilmiah. Nabi hadir membawa ajaran akhlaqul karimah, masyarakat Arab ramai-ramai menentangnya.Banyak fitnah yang diarahkan kepada Nabi namun, kemuliaan akhlaqul karimah, dan dengan karakter agung yang matang, Rasul tetap berperilaku lemah lembut. ${ }^{8}$

Namun Fenomena umat Islam saat ini jauh dari apa yang telah diajarkan oleh Nabi Muhammad. Umat Islam sekarang menjadi baik dan taat hanya ketika "berkomunikasi dengan Sang Pencipta" di mesjid, dan tidak merefleksikan ketaatan tersebut dalam

8 'Aidh bin 'Abdullah Al-Qarni, Visualisasi Kepribadian Muhammad, (terj), (Bandung: Irsyad Baitus Salam, 2006), h. 32 
tindakan horizontal (baca: muamalah), sehingga muncul berbagai penyakit dalam masyarakat seperti kemiskinan, kesyirikan, kezaliman, kemaksiatan, kebodohan, perjudian, minuman keras, pencurian, perzinaan, pembunuhan, perampokan, penodongan, korupsi, pelanggaran Hak Asasi Manusia (HAM) dan sejenisnya. Fenomena ini adalah suatu peringatan untuk mawas diri, agar berusaha menjadikan diri, keluarga, dan lingkungan untuk tetap mempertahankan iman. Ekses yang sangat mendasar dari timbulnya penyakit tersebut adalah timbulnya pendangkalan iman, sebagaimana disinyalir dalam sebuah ungkapan "Hampir saja kemiskinan itu menjadi kekafiran." ${ }^{9}$ Semua itu terjadi karena mereka meninggalkan Amar Ma'ruf dan Nahi Munkar, menuruti hawa nafsu, terpedaya dan tertipu dengan gemerlapnya kehidupan dunia.

Dalam tulisan ini, penulis akan membahas bagaimana Nabi Muhammad melakukan perubahan sosial dalam masyarakat yang sudah berakar mengenai kemusyrikan, perjudian, dan moral, melalui perbuatan, perilaku dan ucapannya dengan menjalankan

9 Jakfar Puteh Saifullah, Dakwah Tektual dan Kontektual Peran dan Fungsinga dalam Pemberdayaan Ekonomi Umat, (Yogyakarta: AK.Group, 2006), h. 1 amarma'ruf dan nahi munkar dengan suatu pendekatan dakwah pada masyarakat Jahiliyah Arab di Makkah.

\section{Pembahasan}

\section{Pengertian Dakwah}

Ditinjau dari segi bahasa, kata dakwah berasal dari bahasa Arab yaitu da'â, yad'û yang berarti panggilan, ajakan, dan seruan. Dalam bahasa Indonesia kata dakwah telah menjadi salah satu kosa kata baku dalam kamus Bahasa Indonesia. ${ }^{10}$ Dakwah adalah bentuk masdar dari kata "دعو"،"دعا" yang bermakna panggilan, seruan atau ajakan.Dakwah dalam makna itu banyak ditemukan dalam Alquran misalnya QS. Yusuf: 33 dan QS. Yunus: 25. Dakwah secara etimologi berasal dari asal kata al-dâl (الدال), al'ain (العين) dan salah satu huruf mu'tal yang bermakna; condongnya sesuatu kepadamu dengan suara atau ucapan. ${ }^{11}$ Sedangkan dakwah secara terminologi menurut Departemen Agama RI "Metodologi Dakwah kepada Suku Terasing", yakni dakwah adalah setiap usaha yang mengarah untuk memperbaiki suasana

10 Departemen Pendidikan dan Kebudayaan, Kamus Besar Bahasa Indonesia, Jakarta: Balai Pustaka, 1990, h.181

11 Abu Husain Ahmad bin Faris bin Zakariya, Mu'jam al-Maqayis alLughah,(Beirut: Dar al-Fikr, 1994) h. 350 
kehidupan yang lebih baik dan layak, sesuai dengan kehendak dan tuntunan kebenaran. ${ }^{12}$

Pada hakikatnya amar maruf dan nahi munkarterdapat empat penggalan kata yang apabila dipisahkan satu sama lain mengandung pengertian sebagai berikut: مر: memerintah atau menyuruhisyang baik atau kebaikan/kebajikan, نهي: larangan dan منكر:perkara yang keji. Manakala keempat kata tersebut digabungkan, akan menjadi: المنكر عنو النهيمعروفامربا yang artinya menyuruh yang baik dan melarang yang buruk. ${ }^{13}$ Allah berfirman: وتعاونواعلى البرو التقوى و لاتعاونواعلى الاثم والعدوان “Tolong menolonglah kamu dalam berbuat kebajikan dan bertaqwalah, serta jangan tolong menolong dalam hal dosa dan kejahatan". (QS. Al Maidah: 2) Al-Qurtubi menguraikan dalam ayat ini bahwa Allah swt memerintahkan kepada utusan-Nya untuk mengajak umat manusia ke jalan Allah dan syari'at-Nya dengan cara halus dan lemah lembut (latif), tidak boleh dengan kasar dan keras.). ${ }^{14}$ Ma'ruf diambilkan

12 Asmuni Syakir, Dasar-Dasar Strategi Dakwah Islam, (Surabaya: al-Ikhlas, 1983), h. 20

13 Khairul Umam, A Ahyar Aminuddin, Usul Fiqih II, (Bandung: Pustaka Setia, 1998), h.97

14 Muhammad al-Qurtubi, Juz 10, alJami' li Ahkam al-Quran, Juz IV, (Bairut: Dar alKutub al-Arabiyyah, 1993), h.131 dari kata ma'rifah suatu kata yang diketahui oleh hati dan menenangkannya, dan dengannya jiwa merasa sakinah. menurut syari'at adalah taat dan berbuat baik kepada hambaNya. Sedangkan munkar adalah tidak diterima, dibenci dan tidak diketahui. Sedangkan menurut syari'at adalah semua yang diketahui oleh syari'at maupun akal tentang jeleknya, yakni maksiat kepada Allah swt dan menzalimi hamba-Nya. ${ }^{15}$

Dakwah adalah seruan atau ajakan kepada keinsafan, atau usaha mengubah situasi kepada situasi yang lebih baik dan sempurna, Perwujudan dakwah bukan sekadar usaha peningkatan pemahaman keagamaan dalam tingkah laku dan pandangan hidup saja tetapi juga menuju sasaran yang lebih luas, menyeluruh dalam berbagai aspek kehidupan. ${ }^{16}$ Oleh karena itu, untuk mewujudkan masyarakat yang baik, maka dibutuhkan suatu gerakan dakwah yang terorganisir yang tidak hanya mengedepankan bentuk dakwah lisan semata, tapi juga dengan dakwah bil hal yang diiringi dengan sebuah

15 Salman Bin Fahd Al-'Audah, urgensi Amar Ma'ruf Nahi Mungkar, (Solo: Pustaka Mantiq, 1996), h. 13

16 M. Quraish Shihab, Membumikan AlQur'an Fungsi dan Peran Wahyu dalam Kehidupan Masyarakat, (Bandung: Mizan, 1994), h. 194 
gerakan dinamis yang berorientasi pada pembinaan, pelatihan dan pengembangan masyarakat berupa pelayanan, bantuan sosial, dan pembinaan yang berskala sehingga terwujud kesejahteraan ${ }^{17}$ dan juru dakwah sebagai actor dakwah baik secara fardiyah maupun jam'iyah mampu melahirkan dan meluruskan pemahaman tentang makna dakwah berorientasi pada amar makruf nahi munkar dalam upaya menkontruksi masyarakat sesuai dengan petunjuk Allah dan Rasul-Nya ${ }^{18}$ yang terdiri dari individu atau kelompok, sehingga tersusun tatanan kehidupan keluarga (usrah), kelompok sosial (jama'ah), dan masyarakat yang baik (khairu ummah) dengan berkualitas sesuai tuntunan Alqur'an dan hadis. Dengan demikian dari mobilisasi sosial tersebut, dan yang pada gilirannya merupakan daya pendorong terbentuknya sistem sosial di mana dakwah itu dilaksanakan. ${ }^{19}$

\section{Sejarah Dakwah Nabi Muhammad}

17 Muhammad Sulthon, Desain Ilmu Dakwah, (Semarang: Pustaka Pelajar, 2003), h.vii

18 M. Jakfar Puteh dan Sifullah, Dakwah Tekstual dan Kontekstua; Peran dan Fungsinya Dalam Pemberdayaan Ekonomi Umat, (Yogyakarta: AK Group, 2006), h. 5

19 Miftah Faridl, Dakwah Kontemporer, (Bandung: Pusdai Press, 2000), h. vii
Berdasarkan sejarah dakwah nabi dan para sahabatnyatidak pernah menggunakan senjata untuk memaksa seseorang untuk masuk agama Islam. Secara konseptual, Muhammad Ghazali menyatakan bahwa ada tiga tahap dakwah Nabi untuk menyadarkan umatnya, yaitu 1) proses menyadarkan pikiran, 2) menumbuhkan keyakinan, dan 3) membangun sistem (organisasi). Jika dikontekskan pada langkah-langkah dakwah Nabi, disebutkan pada tahap pertama dan kedua adalah priode Makkah. Menyadarkan masyarakat jahiliyah bahwa agamanya adalah batil dan cara bertuhannya sesat. Setelah itu, Rasul menawarkan satu sistem kepercayaan dan aqidah dan beribadah yang murni bersih dan lurus yaitu Islam.Kemudian tahap ke tiga merupakan periode membangun tatanan sistem sosial yang bernafaskan Islam, dari sistem ekonomi hingga kekuasaan kenegaraan ada pada priode Madinah. ${ }^{20}$ Lawan utama dari dakwah Islam Nabi, yaitu kekuasaan dan kapital setelah sistem kepercayaan.Meski gambaran masayarakat jahiliyah sedemikian luar biasa buruk, Menurut

20 Amrullah Ahmad, (ed), Dakwah Islam dan Perubahan Sosial, (Yogayakarta: PLP2M, Yogyakarta, 1985), h. 4-5 
Karen Amstrong, Islam datang pada waktu yang sangat tepat. ${ }^{21}$

Nabi Muhammad memiliki dua strategi dasar dalam perubahan masyarakat jahiliyahpada periode Makkah, yaitu pertama, dakwah secara sembunyi melalui pendekatan individual (personal approach) dengan mendekati keluarga, dan sahabat terdekat untuk mendapatkan dukungan, untuk mengikuti, menyakini, memahami, dan mengamalkan ajaran Islam, Kedua, dakwah secara terangterangan, melalui pendekatan kolektifseperti yang dilakukan saat berdakwah ke Thaif dan pada musim haji. (QS. al-Syu'arâ : 214), Nabi mulai menyampaikan risalah Islam secara terbuka. Semangat dakwah Rasul semakin kuat ketika firman Allah turun dalam (QS. al-Hijr:94). Dengan turunnya ayat tersebut, Nabi Muhammad semakin gencar mendakwahkan Islam baik secara sembunyi maupun terangterangan. Bahkan beliau telah mendemonstrasikan salat di dekat Ka'bah, sehingga setiap orang yang melintas dapat menyaksikannya. Sehingga terjadilah peristiwa Uqbah bin Abî Mu'ith menginjak tengkuk Nabi

\footnotetext{
21 Karen Armstrong, Sejarah Muhammad; Biografi Sang Nabi, (terj), (Magelang: Pustaka Horizona, 2007), h. 75
}

ketika beliau bersujud sehingga hampirhampir keluar kedua biji matanya. ${ }^{22}$

Selain itu, Nabi Muhammad mendapatkan dukungan dari pamanya Abu Țālib, akan tetapi setelah pamannya meninggal dunia tak ada lagi orang yang melindunginya. Meninggalnya Abu Țālib tak lama kemudian Siti Khadijah istri tercintanya wafat, maka tahun ini sering disebut dengan tahun duka cita. ${ }^{23}$ Dalam tulisan Muhammad al-Ghazali, Sejarah Perjalanan Hidup Muhammad, menyebutkan bahwa untuk membendung orang-orang Quraish tidak hanya menyiksa Nabi, namun mereka juga menyiksa kaum muslimin. Misalnya mereka menyiksa 'Ammār bin Yasir dan kedua orang tuanya (Yasir dan Sumayyah). Ammār bin Yasir adalah seorang maula (bekas budak yang hidup di bawah naungan bekas tuannya) Bani Makhzum.Ia termasuk orang yang paling awal masuk Islam bersama kedua orang tuanya. Ia diseret oleh kaum musyrikin, kemudian di bawa ke tengah padang pasir yang sedang panaspanasnya kemudian disiksa dengan kejam. Pada saat mereka disiksa luar

22 Syaikh Shafiyyurrahman alMubarakfuri, Perjalanan Hidup Rasul Yang Agung Muhammad; Dari Kelahiran Hingga Detikdetik Terakhir, (Jakarta: Kantor Atase Agama Kerajaan Saudi Arabia, 2001), h.131

23 Bisri M. Djaelani, Sejarah Nabi Muhammad Saw, (Yogyakarta: Penerbit Buana, 2004), h.115 
biasa itu, Rasulullah saw lewat dan beliau berkata, "Hai keluarga Yasir, tabahlah! Allah telah menjanjikan surga bagi kalian". ${ }^{24}$

Berbagai cara dan taktik yang dilakukan oleh orang Quraish Makkah untuk menghentikan dakwah Nabi. Namun Abu TTālib merespon dengan perkataan yang lembut dan sopan dengan menolak permintaan kaum Quraish, bahkan Nabi Muhammad menyatakan: "wahai paman, demi Allah, sendainya mereka meletakkan matahari di tangan kananku dan bulan di tangan kiriku agar aku meninggalkan urusan ini, niscaya aku tidak akan meninggalkannya hingga Allah memenangkan atau aku binasa." 25 Cara lain untuk membenamkan dakwahNabi denganejekan, penghinaan, dan olokolok, untuk melemahkan kekuatan moral dan kekuatan fisik para pengikut Nabi Muhammad.Orang-orang Quraish melemparkan berbagai tuduhan yang lucu dan ejekan terhadap Nabi Muhammad.Bahkan mereka menyebut Nabi sebagai orang yang sinting atau gila.QS: 15 (al- Hijr):6. Selain itu juga

24 Muhammad al-Ghazali, Sejarah Perjalanan Hidup Muhammad, Terj. Imam Muttaqien, (Yogyakarta: Mitra Pustaka, 2003), h.113

25 Abul Hasan 'Ali al-Hasani an-Nadwi, Sirah Nabawiyah; Sejarah Lengkap Nabi Muhammad, (Yogyakarta: Mardiyyah Press, 2006), h.127 disebut sebagai tukang sihir dan pendusta.Seperti dinyatakan oleh AlWalid bin Mughirah "Muhammad adalah seorang penyihir yang datang dengan sihirnya. Ia hendak memisahkan antara anak dengan ayahnya, seseorang dengan saudaranya, seseorang dengan istrinya atau seseorang dengan keluarganya." 26

Nabi Muhammad dalam melakukan suatu perubahan sosial menitipberatkan kepada tiga bidang yaitu a) bidang agama, b) bidang moral, dan c) bidang hukum, yang disebut pertama, masyarakat Arab jahiliyah sudah jauh menyimpang dari ajaran agama Hanifyang telah diajarkan oleh Nabi Ibrahim AS. Masyarakat Arab jahiliyah umumnya beragama watsani atau agama penyembah berhala yang terletak di Ka'bah dengan jumlah kurang lebih 360. Di antara berhalaberhala yang termashyur bernama: Ma'abi, Hubal, Khuza'ah, Lata, Uzza, dan Manat. Sebagian masyarakat Arab jahiliyah menyembah malaikat dan bintang yang dilakukan kaum Sabi'in dan sebagian masyarakat di luar Kota Mekkah menyembah matahari, bulan, dan jin.

Yang disebut kedua, masyarakat Arab jahiliyah telah menempuh cara26 Ibid, h.135. 
cara yang sesat, misalnya jika terjadi peperangan antar kabilah, maka kabilah yang kalah perang akan dijadikan budak oleh kabilah yang menang perang. Dalam masyarakat Arab jahiliah perempuan tidak berhak mewarisi harta peninggalan suaminya, ayahnya, atau anggota keluarga yang lain. Bahkan seorang wanita (istri) boleh diwarisi oleh anak tirinya atau anggota keluarga lain dan suaminya yang telah mati. Kehadiran Nabi Muhammad saw sebagai Nabi revolusioner mengangkat derajat perempuan, dan disejajarkan dengan laki-laki, tetapi pensejajaran ini tidak menghapus sifat keperempuanan seorang wanita, sebuah emansipasi benilai keislaman yang memiliki hakhak perempuan yang menjaga kehormatan dan kemuliannya sebagai seorang perempuan yang punya kesempatan untuk mendapat pahala dan kemuliaan di sisi Allah.

Ajaran Islam mendapat banyak penolakan dan tantangan dari berbagai kalangan pembesar masyarakat Arab Quraisy saat itu.Adanya penolakan tersebut tentu sebuah kelaziman /kewajaran, mengingat Islam sebuah ajaran baru yang tentu saja berbeda dengan keyakinan yang sudah lama dianut oleh masyarakat Arab saat itu.Nabi Muhammad membawa misi ini tidak berbeda dengan ajaran Nabi Ibrani dan Injil perjanjian Lama, yang isinya mengajak kepada percaya kepada satu Tuhan, percaya kepada kehidupan sesudah mati, dan mendapatkan siksaan bagi yang melanggarnya dan sebaliknya mendapatkan pahala bagi yang mentaatinya. ${ }^{27}$

Kehidupan dakwah Islam, baik dalam posisinya sebagai kegiatan sosiorelijius maupun dalam tataran historis emperis, harus menjadi bagian dari konsep maupun gerakan sistematis yang memberikan kontribusi bagi upaya merubah suatu masyarakat menuju arah yang lebih baik. Nabi dalam merubah suatu budaya, keyakinan, dan karakter memiliki waktu yang sangat singkat hanya 63 tahun jika dibandingkan dengan revolusi industri di Inggris yang disebut-sebut sebagai tonggak perubahan masyarakat Barat menuju kehidupan yang rasional. revolusi Inggris benar-benar berjalan dalam durasi waktu sekitar 100 tahun yaitu 1760 sampai dengan 1860.

\section{Hadis Dakwah Tentang Amal Ma'ruf dan Nahi Munkar} Apabila manusia melihat kemunkaran dan tidak bisa

27 Philip K. Hitti, the Arabs A Short Story, terj. Ushuluddin Hutagalung, t.th, t.tp,h.35 
merubahnya, diawatirkan Allah akan melimpahkan azab siksa-Nya secara merata, ${ }^{28}$ jika kemaksiatan sudah menjadi kebiasaan di tengah masyarakat, dan orang-orang yang beriman tidak peduli dan tidak berusaha untuk mencegah kemaksiatan itu, maka Allah swt akan menimpakan azab kepada suatu kaum tanpa memandang baik orang-orang yang jahat maupun orang-orang yang beriman.

Nabi Muhammad saw, bersabda bahwa adasekelompok kaum yang mengundi di atas kapal, sebagian mereka ada di atas kapal dan sebagian yang lainnya harus tinggal di bagian bawah. Manakala orang yang tinggal di bagian bawah kapal ingin minum, (maka aturannya) mereka harus naik (dan melangkahi) orang-orang yang tinggal di bagian atas kapal. Maka berkatalah mereka (orang-orang yang di bagian bawah kapal), jika kita melobangi kapal ini dan kita tidak lagi merepotkan orang atas, (hal ini akan lebih memudahkan tentunya). Jika sekiranya mereka membiarkan kelompok ini dan apa-apa yang mereka inginkan, maka binasalah semuanya, dan jika mereka menahan

28 Ali Usman Dahlan,t.th, Hadits Qudsy Pola Pembinaan Akhlak Muslim, (Bandung: CV. Diponegoro), h.373 perbuatan kelompok ini, maka mereka selamat, dan selamatlah semuanya". ${ }^{29}$

Perupamaan hadis di atas, sangatlah jelas dan mudah dipahami sebagai way of life dalam kehidupan bermasyarakat.Jika terjadi suatu kemunkaran dalam kehidupan komunitas kemudian didiamkan dan tidak ada terpetik dalam hati untuk mencegahnya, maka masyarakat sedang menunggu kebinasaan, sebaliknya binasa pulalah orang yang membiarkannya. Gambaran di atas menunjukkan bahwa umat Islam harus berusaha melaksanakan amar ma'ruf dan nahi munkar menurut kemampuannya, sekalipun hanya melalui hati. ${ }^{30}$ Dengan sikap dan perilaku untuk menegakkan, memelihara, dan memperjuangkan kebenaran agama Allah, menganjurkan kepada manusia berbuat yang ma'ruf dan mencegah perbuatan yang munkar. ${ }^{31}$ Karena sesungguhnya apabila orang-orang melihat orang yang bertindak aniaya kemudian mereka tidak mencegahnya, maka kemungkinan besar Allah akan meratakan siksaan kepada

\footnotetext{
${ }^{29}$ HR. Bukhari: Shahih Bukhari, Juz III, h.181

30 Rachmat syafe'i, Al-Hadis Aqidah,Akhlak, Sosial, dan Hukum, (Bandung: Penerbit Pustaka Setia, 2000), h.241

31 Abdul Hamid Ritonga, Hadis Seputar Fiqih dan Sosial Kemasyarakatan, (Bandung: Cita pustaka Media Perintis, 2009), h.88-89).
} 
mereka, disebabkan perbuatan tersebut. $^{32}$

Pada hadis lain yang diriwayatkan oleh MuslimNabi Muhammad saw bersabda:

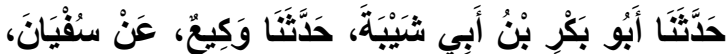

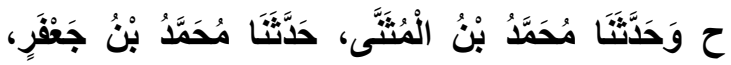

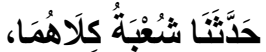

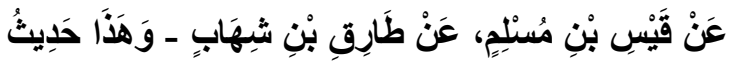


الصَّلَاةِ مَرْوَانُ. فَقَََمَ



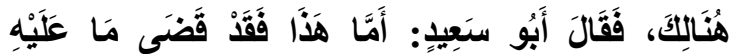
سَمِمْتُ رَسُوْلَ اللهِ

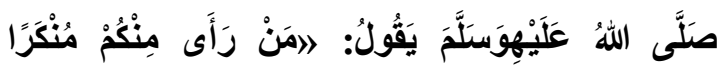

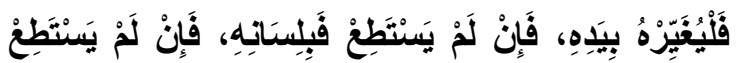

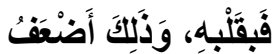

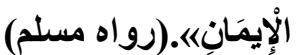

Artinya:

Abu Bakar bin Abu Syaibah telah menceritakan kepada kami,Waki' telah menceritakan kepada kami dari Sufyan. (dalam riwayat lain disebutkan) dan Muhammad bin al-Mutsanna telah menceritakan kepada kami,Muhammad bin Ja'far telah menceritakan kepada kami,Syu'bah keduanya telah menceritakan kepada kami dari Qais bin Muslim dari Thariq bin
Syihab dan ini adalah hadis Abu Bakar, "Orang pertama yang berkhutbah pada Hari Raya sebelum salat hari raya didirikan ialah Marwan. Lalu seorang lelaki berdiri dan berkata kepadanya, "Salat hari raya hendaklah dilakukan sebelum membaca khutbah."Marwan menjawab, "Sungguh, apa yang ada dalam khutbah sudah banyak ditinggalkan." Kemudian Abu Said berkata, "Sungguh, orang ini telah memutuskan (melakukan) sebagaimana yang pernah aku dengar dari Rasulullah saw, bersabda: "Barangsiapa di antara kamu melihat kemunkaran hendaklah ia mencegah kemunkaran itu dengan tangannya, jika tidak mampu, hendaklah mencegahnya dengan lisan, jika tidak mampu juga, hendaklah ia mencegahnya dengan hatinya. Itulah selemahlemah iman.Terdapat juga 33" riwayat hadis dari Ibn Majah ${ }^{34}$ dan hadis ini berkualitas shahih.

33 Abu Husayin Muslim Ibn Hajjáj alQusyayri Al-Naisaburi, Shahih Muslim, Juz I, Bairut; Ísá al-Báby al-Halaby waa al-Syurakah, 1395/1955:Juz I/69

34 Sunan ibn Majah,Juz II, h. 1330, Abu Daud Juz I, h. 296, an-Nasa'i Juz , VIII, h. 111 
Dari hadis tersebut terdapat tiga tahapan metode yaitu; Metode dengan tangan, metode dengan lisan dan metode dengan iman.Metode pertama dipahami secara tesktual, hal ini terkait dengan bentuk kemunkaran yang dihadapi oleh manusia ada yang mengubah kemunkaran dengan cara mempraktikkan dengan tangannya sebagai kekuatan tubuh dan diri. Secara kontekstual dipahami merubah suatu kemunkaran dengan kekuasaan atau power.Metode kedua adalah metode dakwah dengan lisan, kata-kata yang lemah lembut (latif),bukan dengan katakata yang keras, kasar, dan menyakitkan hati,misalnya memberikan ucapan yang baik, berdiskusi secara ilmiah, bentuk tulisan, dan lain-lainnya.Langkah menghentikan kemunkaran dengan lisan dilakukan apabila langkah kekuasaan/power tidak dapat dilaksanakan, sedangkan yang disebut terakhir adalah metode iman, ada di antara manusia yang sangat lemah dan tidak mampu mencegah kemunkaran melainkan dengan hatinya, Merubah dengan hati artinya membenci kemunkaran dengan hati. Bahkan Allah swt dan Rasul-Nya mengancam dengan sangat keras bagi siapa yang tidak melaksanakannya, sementara ia mempunyai kemampuan dan kewenangan. ${ }^{35}$ Selain dari metode tersebut, menurut penulis masih ada metode yang lebih utama yaitumetode bil uswatun hasanah, yaitu dengan memberi contoh prilaku yang baik dalam segala hal. Keberhasilan dakwah Nabi Muhammad saw ditentukan oleh akhlaq karimah di mana satunya perkataan dan perbuatan dalam kehidupan sehari-hari.

Hadis di atas merupakan titik utama dalam merubah nahi munkar menuju amal ma'ruf.oleh karena itu, para ulama konsensus memasukkannya sebagai pokok-pokok ajaran agama, bahkan dikatakan kandungan hadis ini sebagian dari syari'ah, sebab syari'at ini terdiri dari dua perkara, yaitu perkara yang ma'ruf, maka wajib dilaksanakan atau perkara yang munkar,maka wajib dicegah. Hadis ini pula menjelaskan tentang tingkatan dalam melakukan amar ma'ruf dan nahi munkar, yaitu mengingkari kemunkaran dengan tingkatan pertama tangan dan tingkatan kedua lisan dan hal ini wajib dilaksanakan sesuai dengan kemampuan dan kekuatan dengan syarat tidak mendatangkan kemunkaran yang lebih besar. Tingkatan ketiga adalah mengingkari

35 Teungku Muhammad Hasbi Ash Shiddiqey, Al-Islam, (Semarang: PT. Pustaka Rizki Putra, 2001), h.348. 
dengan hati, maka hal ini menuntut bagi seorang hamba untuk meninggalkan tempat yang menjadi basis kemunkaran tersebut. ${ }^{36}$ Hadis ini juga secara zahir menunjukkan kepada individu atau seseorang yang mampu mencegah kemunkaran dengan tangan atau kekuasaan, namun membiarkannya, maka yang demikian tercelah.

Menurut hemat penulis bahwa dalam hadis ini, mengandung isyarat adanya rasa peduli antara satu sama lain dengan meningkatkan hubungan horizontal sesama ciptaan Allah, sehingga kehidupan bermasyarakat menjadi harmonis tanpa ada rasa perbedaan suku, agama dan warna kulit. Perintah melakukan kebaikan dan mencegah kemunkaran itu wajib dilakukan dengan mencurahkan seluruh potensi yang pada diri atau kelompok.Secara empiris membuktikan bahwasanya jika kemunkaran dibiarkan begitu saja dan tidak diubah, maka tidak lama kemudian kemunkaran tersebut akan dianggap sesuatu yang biasa, wajar dan dikerjakan secara beramai-ramai. Jika hal itu terjadi, maka kemunkaran tersebut sulit untuk dihilangkan.

36 Amin bin Abdullah asy-Syaqawi, Urgensi Amar Ma'ruf Nahi Mungkar, الأمر d بالمعروف والنهي عن المنكرم) Indonesia - Indonesian - ] Terjemah, Muzaffar Sahidu, Editor : Eko Haryanto Abu Ziyad, 2010- 143, h.4
Demikian juga jika kemunkaran dalam masyarakat muslim dibiarkan merajalela dan kebaikan tidak diperintahkan kepada mereka, maka tidak lama berselang mereka berrohani buruk atau orang-orang jahat, tidak menyuruh kepada kebaikan, dan tidak melarang dalam kemunkaran. Dari hasil pengamatan sehari-hari dapat diktakan bahwa jika jiwa manusia terbiasa dengan keburukan, maka keburukan tersebut akan menjadi wataknya. Itulah kerja amar ma'ruf dan nahi munkar ${ }^{37}$ dan ketika orang melakukan dosa dan maksiat tanpa ada rasa keberanian untuk menegurnya dengan membiarkan begitu saja, maka tunggulah kehancuran dan kebinasaan, dan ketika umat ini takut mengatakan yang hak dan tidak mencegah orang yang berbuat zalim. ${ }^{38}$

Untuk mewujudkan hal di atas, Muhammad saw berusaha mengambil hati umatnya dengan akhlak yang baik, dan ajaran-ajaran yang disampaikan sesuai dengan tingkat pemahaman dan dapat diterima oleh akal manusia, maka tidak heran jika Allah menerangkan bahwa Muhammad saw sebagai Nabi Revolusioner pembawa rahmat.

37 Abu Bakr Al-jazairi, Minhajjul Muslim, (Beirut: Darul Fikr, t.th), h. 88

38 Ghazali, Mukasyafatul Qulub, Terj. Fatihuddin Abul Yasin, (Surabaya: Terbit Terang, 1990), h. 86 
"Tidaklah kami mengutus engkau (wahai Muhammad), melainkan sebagai rahmat untuk seluruh alam,"(QS. Al-ahzab: 21).

\section{Kesimpulan}

Sikap acuh tak acuh dan tidak peduli terhadap amar ma'ruf dan nahi munkar merupakan suatu bahaya dan kehancuran.Menegakkan amarma'ruf dan nahimunkartentu saja membutuhkan perjuangan, dan pengorbanan baik materi maupun non materi dalam melaksanakanya. Nabi Muhammad diangkat menjadi utusanNya tidak untuk dipuji, disanjung, dijunjung tinggi, dan tidak untuk di kultuskan, tetapi untuk diikuti risalanya, dituruti tuntunannya dalam hal cara beribadah kepada-Nya, dan untuk dicontohi akhlakul karim dalam tata cara bergaul dan bermasyarakat antar sesama manusia.Melihat realitas umat Islam saat ini, dengan berdasarkan pada tiga metode perubahan yaitu metode dengan tangan, lisan dan hati untuk melakukan amar ma'ruf dan nahi munkardalam masyarakat bahwa amar ma'ruf dan nahi munkar bisa menyelamatkan orang tidak bersalah, orang bermaksiat dan juga orang lain yang taat dan istiqamah.

\section{Daftar Pustaka}

'Aidh bin 'Abdullah Al-Qarni, Visualisasi Kepribadian Muhammad, (terj), Bandung: Irsyad Baitus Salam, 2006.

Abd. Rosyad Saleh, Manajemen Dakwah Islam, Jakarta: Bulan Bintang 1977.

Abdul Hamid Ritonga, Hadis Seputar Fiqih dan Sosial Kemasyarakatan,Bandung:

Citapustaka Media Perintis, 2009.

Abdul Karim Zaidan, Dasar-Dasar Dakwah, Jakarta: Pustaka Firdaus, 1980.

Abu Abdullah Muhammad ibn Ismã'il ibn Ibrahim ibn al-Mughirah ibn al-Bardizbat Al-Bukhari, Shahih al-Bukhari, Juz. III, Semarang; Maktabatuh Wa matba'atu Thaha Putra T.th.

Abu Abudrrahman bin Syu'ayb AlNasaiy, Sunan al-Nasa'iy, Juz VIII, Mesir: al-Babiy al-Halabiy wa Awladuh 1964.

Abu Bakr Al-jazairi. Minhajjul Muslim, Beirut: Darul Fikr, t.th. 
Abu Husain Ahmad bin Faris bin Zakariya, Mu'jam al-Maqayis al-Lughah,Beirut: Dar al-Fikr, 1994.

Abu Husayin Muslim Ibn Hajjáj alQusyayri Al-Naisaburi, Shahih Muslim, Juz I, Bairut; Ísá al-Báby al-Halaby waa al-Syurakah, 1395/1955.

Abu Husayin Muslim Ibn Hajjáj alQusyayri Al-Naisaburi, Shahih Muslim, Juz I, Bairut; Ísá al-Báby al-Halaby waa al-Syurakah, 1395/1955.

Abu Sulaiman ibn ibn al-Asy'as Sijistaiy,,Sunan Abu Dawud, Juz I, Bairut: ar al-'Fikr, 1968

Abul Hasan 'Ali al-Hasani an-Nadwi, Sirah Nabawiyah; Sejarah Lengkap Nabi Muhammad, Yogyakarta: Mardiyyah Press, 2006.

Ahmad Abdurraziq al-Bakri. Ringkasan Ihya 'ulumuddin Imam Ghazalicetakan ke VI.Jakarta: Sahara Publishers. 2010.

Ahmad Iwudh Abduh, Mutiara Hadis Qudsi, Bandung: Mizan Pustaka, 2006.
Ali Usman Dahlan. Hadits Qudsy Pola Pembinaan Akhlak Muslim, Bandung: CV. Diponegoro.

Amin bin Abdullah asy-Syaqawi, Urgensi Amar Ma'ruf Nahi Mungkar, الأمر بالمعروف والنهي عن المنكرم) Indonesia - Indonesian - إندونيسي ]Terjemah, Muzaffar Sahidu, Editor : Eko Haryanto Abu Ziyad 2010 1431, Islamhouse.com.

Amrullah Ahmad (ed), Dakwah Islam dan Perubahan Sosial, Yogayakarta: PLP2M, Yogyakarta, 1985.

Asmuni Syakir, Dasar-Dasar Strategi Dakwah Islam, Surabaya: alIkhlas, 1983.

Bisri M. Djaelani, Sejarah Nabi Muhammad Saw, Yogyakarta: Penerbit Buana, 2004.

Departemen Agama RI, Alquran dan Terjemahnya, Bandung: Syaamil Cipta Media, 1426 H./2005.

Departemen Pendidikan dan Kebudayaan, Kamus Besar Bahasa Indonesia, Jakarta: Balai Pustaka, 1990. 
Imam Ghazali, Mukasyafatul Qulub, Terj.

Fatihuddin Abul Yasin, Surabaya:

Terbit Terang, 1990.

Ismail Ibn Kasir, Tafsir al-Quran al'Azim, Juz 1, Bairut: Dar al Ihya al-Turas al-'Arabi.

Jakfar Puteh Saifullah, Dakwah Tekstual dan Kontekstua; Peran dan Fungsinya Dalam Pemberdayaan Ekonomi Umat, Yogyakarta: AK Group, 2006.

Juwar iyah.Hadis Tarbawi, Yogyakarta: Sukses Offset. 2010.

Karen Armstrong, Sejarah Muhammad; Biografi Sang Nabi, (terj), Magelang: Pustaka Horizona, 2007.

Khairul Umam, A Ahyar Aminuddin, Usul Fiqih II, Bandung: Pustaka Setia, 1998.

M. Jakfar Puteh dan Sifullah (ed), Dakwah Tektual dan Kontektual Peran dan Fungsinga dalam Pemberdayaan Ekonomi Umat, Yogyakarta: AK.Group, 2006.

M.Quraish Shihab, Membumikan AlQur'an Fungsi dan Peran Wahyu dalam Kehidupan Masyarakat, Bandung: Mizan, 1994.

Majah, Abu Abdullah Muhammad bin Yazid al-Qazwiniy Ibn Majah, Sunan ibn Majah, Juz II,Bairut: Daral-Fikr, t.th.

Miftah Faridl, Dakwah Kontemporer, Bandung: Pusdai Press, 2000.

Muhammad al-Ghazali, Sejarah Perjalanan Hidup Muhammad, Terj. Imam Muttaqien Yogyakarta: Mitra Pustaka, 2003.

Muhammad al-Qurtubi, al-Jami' li Ahkam al-Quran, Juz IV, Bairut: Dar al-Kutub al-Arabiyyah.

Muhammad al-Qurtubi, al-Jami' li Ahkam al-Quran, Juz X, Bairut: Dar al-Kutub al-Arabiyyah, 1993.

Muhammad Sulthon, Desain Ilmu Dakwah, Semarang: Pustaka Pelajar, 2003.

Philip K. Hitti, the Arabs A Short Story, terj.Ushuluddin Hutagalung, t.th, t.tp.

Rachmat syafe'i, Al-Hadis Aqidah,Akhlak, Sosial, dan Hukum, Bandung: Penerbit Pustaka Setia, 2000. 
Salman Bin Fahd Al-'Audah, urgensi Amar Ma'ruf Nahi Mungkar, Solo: Pustaka Mantiq, 1996.

Syaikh Shafiyyurrahman alMubarakfuri, Perjalanan Hidup Rasul Yang Agung Muhammad; Dari Kelahiran Hingga Detikdetik Terakhir, Jakarta: Kantor Atase Agama Kerajaan Saudi Arabia, 2001.

Teungku Muhammad Hasbi Ash Shiddiqey, Al-Islam, Semarang: PT. Pustaka Rizki Putra. 2001. 